\title{
Study on the Cultivation Mode of Business English Talents under "the Belt and Road Initiative"
}

\author{
Xiaomei Wang \\ School of Applied Science and Technology, Beijing Union University, Beijing 100101, China.
}

Keywords: The Belt and Road Initiative; Business English; talent cultivation; multiple evaluations

Abstract. The Belt and Road Initiative puts forward new requirements for business English talents. Based on the analysis of the new requirements, the study first presents the problems in the present business English talent cultivation. In order to meet the needs in the new situation, the study explores effective ways to cultivate applied Business English talents from three aspects, the setting of business English curriculum, business English practice teaching, and multiple evaluations, and puts forward new mode of Business English talents cultivation.

\section{Introduction}

The Belt and Road Initiative was proposed by President Xi Jinping in the autumn of 2013 to build the "New Silk Road Economic Belt" and the " $21^{\text {st }}$-century Maritime Silk Road", aiming to enhance complementarity and synergy of development strategies and promote common progress of participating countries through closer international cooperation. On October 18, 2017, President Xi emphasized at $19^{\text {th }}$ National Congress of the Communist Party of China that we should pursue the Belt and Road Initiative as a priority, give equal emphasis to "bringing in" and "going global", follow the principle of achieving shared growth through discussion and collaboration, and increase openness and cooperation in building innovation capacity. With these efforts, we hope to make new ground in opening China further through links running eastward and westward, across land and over sea. The Belt and Road Initiative is the medium and long-term strategy of our country, and it is also the highest top-level strategy. The core is to achieve policy, infrastructure, trade, financial, and people-to-people connectivity and thus build a new platform for international cooperation to create new drivers of shared development. Language communication is one of the most important foundations for realizing the above Five Connectivity.

Implementing and deepening the Initiative will inevitably bring about an urgent demand for applied business English talents, especially those who are good at English language and business knowledge. Global economy and the Initiative have brought unprecedented opportunities to the development of business English major. Business English talents cultivation objectives are defined by The National Standard for the Teaching Quality of Business English Majors in Colleges and Universities as follows: Business English majors aim to cultivate compound and application-oriented talents who can work in international business environment, with solid basic English skills, international vision and humanistic qualities, and a good master of the basic theories and knowledge of linguistics, economics, management and international business law, familiar with international business rules and practices, with good English application ability, business practice ability, cross-cultural communication ability, thinking and innovation ability, self-learning ability, etc. The training objectives of business English majors fit well with the basic requirements of the Initiative for applied Business English talents.

At present, applied business English talents are mainly cultivated by colleges and universities in China. This study conducted a questionnaire survey on business English Majors in Beijing universities. Fig. 1 shows the survey result. It is clear that there exist many problems to be solved in business talents cultivation for colleges and universities. This paper will analyze the current situation and problems in the cultivation of applied Business English talents, and reflect on the countermeasures to deal with these problems, hoping to provide some suggestions for future teaching and talents cultivation.

Higher requirements for the curriculum design of Business English major in Chinese colleges and universities by the Initiative. Business English is a comprehensive subject dominated by English and 
combined with other disciplines such as business activities. Talents cultivation aims to enable students to master English language knowledge, to have good English application skills such as listening, speaking, reading, writing and translation, and to cultivate students' ability to apply modern international business knowledge. The cultivation mode put more emphasis on the ability of combining theory with practice. And skills application ability is the most important in the talents cultivation.

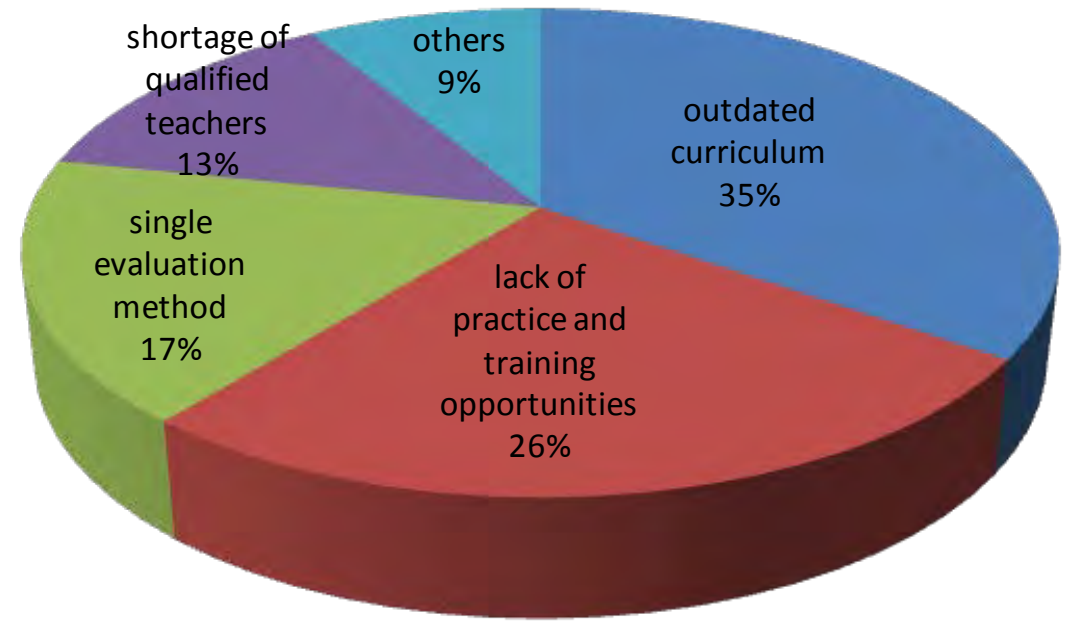

Fig. 1 Current situation and problems for Business English Cultivation in China

However, Business English major is born out of English Language and Literature. Most teachers of Business English major have been engaged in the teaching of English Language, Literature and Translation before. Therefore, most of the business English teachers still follow the traditional teaching methods. The teaching still focuses on explaining words, syntax and business knowledge theory, and training of listening, speaking, reading, writing and translation. The traditional and single teaching method ignores the strong professional and practical nature of business English as ESP, and also makes the students have no enthusiasm for classroom participation.

In terms of curriculum for Business English major, most colleges and universities continue to keep traditional English courses for English Language and Literature. They simply add several business related courses to the curriculum. Authentic business English textbooks are in great demand. In terms of teaching mode, English and business are simply superimposed. Organic integration of English language and Business knowledge is lack.

In real international business environment, talents are required to properly use English language and business knowledge. If talents fail to properly use the language and business knowledge, he is not qualified and doesn't possess good application ability. While teaching theoretical knowledge, we should pay attention to the cultivation of students' practical application ability. Such real difficulties as shortage of double-qualified teachers, lack of practice opportunities have seriously restricted the cultivation of applied Business English professionals.

Based on the new requirements for applied Business English talents by the Belt and Road Initiative, this study explores effective ways in three aspects, Business English curriculum design, Business English practice teaching and school-enterprise cooperation, as well as multiple evaluation system, and puts forward talents cultivation and training mode of applied Business English talents in the new situation.

\section{Optimizing Curriculum Design for Business English Majors}

There are dozens of countries and regions along the Belt and Road, and they are of multi ethnics and religions. National research courses are recommended, aiming to introduce the cultures, economy, politics and thinking patterns of different countries. The courses highlight the symbolic cultural and historical events and political events, international influential brands and enterprises that represent the national image. Under Content Based Instruction (CBI), courses are taught in English. It enables students to improve their English 
language competence in the process of learning business knowledge, to develop their English thinking mode, thus to enhance their ability to engage in business activities and cross-cultural communication in the English working environment.

Cross-culture Business Communication courses are also recommended. Society customs, cultural traditions, inter-lingual and nonverbal communication, communication strategies, business strategies are recommended to integrate into the teaching process and Curriculum of Business English. Intercultural Business Communication is the core theoretical basis for business English research. The hot research areas of cross-cultural business communication include business communication management, business communication content, business communication language, business communicators, business communication culture, business communication relations, business communication research methods, etc. The content helps students have a broad vision and sensitive judgment of business activities, and adapt to the role they should play in business activities as soon as possible.

Based on the talents need by the Belt and Road Initiative, the study designs and puts forward a curriculum system for Business English Majors, as shown in Table 1. According to the training objectives of Business English, the whole talent training program curriculum system is huge, covering a wide range of courses. The number of courses is large and interdisciplinary characteristic is significant. In order to make up for the limited class hours, many courses can be listed as elective courses. Students can choose courses according to their interests and future career direction. It is an effective way for colleges and universities to increase extra-curricular investment, holding some business lectures or seminars, especially for some interdisciplinary courses, to help students broaden their horizons and expand their thinking. Business instructors or business professionals can be employed to introduce the latest business developments, management insights, entrepreneurial process, business operations, etc. Student organizations are encouraged to carry out business English activities, such as simulation scene, case analysis, English debates, etc. Teachers monitor and guide the activities. Open online courses can be introduced in. Internet autonomous learning can be introduced into traditional classroom teaching and learning.

Table 1 Curriculum System for Business English Majors

\begin{tabular}{|c|c|c|c|c|c|}
\hline Numble & $\begin{array}{l}\text { Curriculum } \\
\text { Module }\end{array}$ & Module Function & Main Courses & $\begin{array}{c}\text { Class } \\
\text { hour } \\
\text { ratio(\%) }\end{array}$ & Notes \\
\hline 1 & $\begin{array}{l}\text { English } \\
\text { Language }\end{array}$ & $\begin{array}{l}\text { Cultivating basic skills of } \\
\text { listening, speaking, } \\
\text { reading, writing and } \\
\text { translating in English }\end{array}$ & $\begin{array}{l}\text { Intensive Reading, Listening, Speaking, } \\
\text { Writing and Translation }\end{array}$ & 30 & \\
\hline 2 & $\begin{array}{l}\text { Business } \\
\text { Communica- } \\
\text { tion }\end{array}$ & $\begin{array}{l}\text { Cultivating business } \\
\text { communication skills in } \\
\text { business context }\end{array}$ & $\begin{array}{l}\text { Intercultural business, communication, } \\
\text { Economics, Management, International } \\
\text { Commercial Law, Business negotiation, } \\
\text { International trade, Marketing, Business } \\
\text { English, Correspondence, Interpretation }\end{array}$ & 35 & $\begin{array}{l}\text { Taught } \\
\text { In } \\
\text { English }\end{array}$ \\
\hline 3 & $\begin{array}{l}\text { Business } \\
\text { Practice }\end{array}$ & $\begin{array}{l}\text { Cultivating business } \\
\text { practice ability }\end{array}$ & Business practice、specific-job training & 25 & \\
\hline 4 & Certificate & $\begin{array}{l}\text { Cultivating business } \\
\text { English application ability }\end{array}$ & $\begin{array}{l}\text { Cambridge Business English, Translation } \\
\text { qualification certificate, IELTS, TOEFL, etc. }\end{array}$ & 10 & \\
\hline
\end{tabular}

From the perspective of talents cultivation, it is a good way to embed such certificate training courses as Cambridge Business English (BEC), Interpreter Qualification Certificate, Translation Qualification Certificate, IELTS and TOEFL in the business English curriculum system, which helps to improve students' proficiency in English and business practical skills and ability. When designing a business English course, teachers should link the teaching objectives of the course with the vocational qualification certificate examination closely related to the course so as to integrate the teaching objectives with the vocational qualification examination and adjust the teaching contents. In this way we can not only make students prepare for the examination and pass the vocational qualification examination, but also make the examination play a backwash role in teaching and promote teaching. 


\section{Strengthening Practical Teaching and School-Enterprise Cooperation}

As an application-oriented major, business English teaching should be practical, application-oriented, practical training and school-enterprise cooperation-oriented, and focus on practice teaching, to cultivate students' ability to use English language in their future professional areas. Competence-based and employment-oriented, Business English talents cultivation should aim at practical talents who can meet the needs of professional posts. An important component of Business English talents cultivation is practice training. International Business English talents cultivation should also be implemented in the internship training. First of all, practical teaching and training should take the economic and cultural background of the countries related to the Belt and Road, and business practice scene should be created to comprehensively improve students' language application ability, business practice ability and international communication ability. Secondly, organize students to participate in business fairs involving countries related to the Belt and Road, or to enter into foreign-funded enterprises or joint ventures to carry out internships. Through specific business practice activities, students' business practice ability can be cultivated while the internationalization process is also promoted.

School-enterprise cooperation help improve students' practical operation skills. Through the cooperation between universities and enterprises, talents cultivation is guided by the market development trend and the enterprise's demand. Thus, the talents cultivated can be used directly by enterprises, which will help enterprises implement the talent strategy, meet the demand for skilled talents, and reduce the cost output of training new talents. School-enterprise cooperation is also an important way to promote teaching with research. We use advanced theories to guide practice, and at the same time, we constantly condense, summarize and reflect on teaching practice, from practice to theory, and then make full use of theoretical research results to guide educational practice. Combining teaching and scientific research organically, we can realize the mutual benefits.

School-enterprise cooperation has a history of nearly one hundred years in Western countries. For the diversification of educational concepts, school-enterprise cooperation is also called cooperative education in Western countries. Educational institutions cooperate with industries and carry out educational and teaching activities together. In terms of talents training measures, western countries adopt different strategies according to their own characteristics, such as the dual system in Germany, the alternation of work and study in Britain, the combination of production and study in Korea, the contractual cooperation in the United States and so on. We can study from their successful experience in our Business English talents cultivation.

\section{Conducting Multiple Evaluations}

Business English is a comprehensive and skilled subject. It combines English language with business knowledge and emphasizes the ability to use English in real business situations. The existing teaching evaluation system for business English majors has several problems, namely, the simplification of evaluation content, evaluation methods, evaluation objects and evaluation subjects. In traditional test of business English major in Higher Vocational Colleges in China, English and business knowledge is the main evaluation content. There is no effective evaluation of business ability and cross-cultural communication ability. Vocational skill ability is a complex concept and has a variety of dimensions. So it cannot evaluate students' all-round ability just by written examination and some practical operation. Only through multiple evaluation system in different environments and channels can students' professional ability be well and accurately evaluated.

Therefore, the introduction of multiple evaluations concept into Business English teaching embodies the principles of constructivism and multiple intelligences. Students are encouraged to display their potential and participate actively in the whole learning process and construct their own knowledge actively in real learning situations. Thus the application-oriented and practical features of Business English Subject are well embodied. In the multi-evaluation system of Business English course teaching, multi-evaluation is mainly embodied in the evaluation methods (including formative evaluation and summative evaluation), the evaluation contents (including the evaluation of English language competence, business knowledge, business competence, intercultural communication competence and comprehensive ability), the evaluation subjects 
(including teachers, enterprises, vocational qualification certificates, etc.). The study attempts to establish a multiple teaching evaluation system for business English majors, as shown in Table 2.

Table 2 Multiple Evaluations Form for Business English Majors

\begin{tabular}{|c|c|c|c|c|c|c|c|}
\hline Numble & $\begin{array}{c}\text { Evaluation } \\
\text { Content }\end{array}$ & $\begin{array}{c}\text { Evaluation } \\
\text { Subject }\end{array}$ & $\begin{array}{c}\text { Evaluation } \\
\text { Method }\end{array}$ & Score & Weight (\%) & $\begin{array}{c}\text { Final } \\
\text { Score }\end{array}$ & Total \\
\hline 2 & $\begin{array}{c}\text { English Language } \\
\text { competence }\end{array}$ & Teachers & $\begin{array}{c}\text { Written and } \\
\text { Spoken } \\
\text { examination }\end{array}$ & 20 & & \\
\hline 3 & $\begin{array}{c}\text { Business } \\
\text { Knowledge }\end{array}$ & Teachers & $\begin{array}{c}\text { Written } \\
\text { examination }\end{array}$ & & 20 & 15 & \\
\hline 4 & $\begin{array}{c}\text { Business } \\
\text { competence }\end{array}$ & Enterprise & $\begin{array}{c}\text { Practical } \\
\text { operation }\end{array}$ & & 15 & \\
\hline 5 & $\begin{array}{c}\text { Intercultural } \\
\text { communicative }\end{array}$ & Enterprise & Interview & & & \\
\hline 6 & $\begin{array}{c}\text { Qumpility } \\
\text { Certificate }\end{array}$ & Expert group & $\begin{array}{c}\text { Graduation } \\
\text { defense }\end{array}$ & & 20 & \\
\hline
\end{tabular}

In the multiple evaluation system, evaluation focus should not only be put on English language knowledge and business knowledge, but also on students' ability to apply the language and business knowledge in real cross-cultural business activities. Cultivate students' language competence, business competence and comprehensive ability (such as self-learning strategy, thinking ability, innovation ability, social emotion, learning methods and steps, etc.). Business English talents cultivation should take cultivating language competence as core, highlight intercultural business communicative competence, focus on broad business knowledge, emphasize application ability, thinking ability and innovative ability, develop multi-dimensional thinking and autonomous learning, thus to improve students' comprehensive quality.

\section{Summary}

Foreign trade, especially trade along the countries and regions flourishes with the implementation of "the "Belt and Road initiative", which provides a broad prospect for our Business English professionals, and has also brought new opportunities and challenges to the colleges and universities who cultivates business English talents. Based on the new requirements for applied Business English talents by the Initiative, this paper analyzes the existing problems in Business English talents cultivation mode in Colleges and universities, and probes effective ways from three aspects: curriculum design, practical teaching and school-enterprise cooperation, and multiple evaluation system, and puts forward a new cultivation mode of Business English talents under the new situation.

\section{Acknowledgment}

This study was conducted with the support of "Business English Course Construction under Application-oriented Courses Construction Project of Beijing Union University” (2017-2018).

\section{References}

[1]. Xi Jinping, Secure a Decisive Victory in Building a Moderately Prosperous Society in All Respects and Strive for the Great Success of Socialism with Chinese Characteristics for a New Era, 2017 (10). (In Chinese) 
[2]. Xu Yurong, Zhu Langrong, the Opportunity, Challenge and Reform Direction of Vocational Education Development under "the Belt and Road Initiative" [J], Education and Occupation, 2017(8), pp: 7-13. (In Chinese)

[3]. Hao Tiancong, China Vocational Education in the "the Belt and Road Initiative" Construction: Experience and Challenges [J], Education Development Research, 2017 (17), pp.62-67. (In Chinese)

[4]. People's Republic of China Ministry of Education, Opinions of the Ministry of Education on Deepening the Teaching Reform of Vocational Education and Improving the Quality of Personnel Training in an All-round Way [Z], 2015(6). (In Chinese)

[5]. Yu Jianyao, Liu Fagong, Overview of Business English Courses in China [J], Foreign Language and Foreign Language Teaching, 2013 (3): pp.37-40. (In Chinese)

[6]. Zhong Yaoping, New Idea of Business English Curriculum Based on Demand Analysis [J], Journal of Chengdu Normal University, 2017 (4), pp: 78-83. (In Chinese)

[7]. Etzkowitz. H. \& L. Leydesdorff, The triple helix of university-industry- government relation: A laboratory for knowledge-based economic development[J], EASST Review, 1995(14), pp.14-19.

[8]. Jiang Liping, School-Enterprise Cooperative Development of Business English Major Courses Based on Applied Talent Cultivation Model [J], Higher Education Journal, 2017 (19), pp: 36-38. (In Chinese)

[9]. Chen Zhiqi, Research on the Construction of Multivariate Teaching Evaluation System of Business English in Higher Vocational Colleges [J], Journal of Lanzhou Institute of Education, 2017 (33), pp: 143-145. (In Chinese)

[10]. Yan Ming, "Curriculum-Teaching-Evaluation" Conformity Business English Professional Training Model [J], Journal of Foreign Languages, 2015 (5), pp: 95-98. (In Chinese) 